\title{
Edukacja medialna seniorów. Dobre praktyki na przykładzie działań Lubelskiego Uniwersytetu Trzeciego Wieku
}

\begin{abstract}
Media education for elderly. Good practices on of the activities in University of the Third Age at Lublin

The main purpose of the text is to emphasize the need to educate older people. The generation of current elderly grew up in the analogue society. There is a need to equal opportunities in an active presence in the digital society. Media competences acquired through education will meet the needs of self-fulfillment, entertainment or recognition. In the following article, students of the third-century university presented the reasons for enrolling in computer classes and a seminar on media sciences. They also indicated which computer tools they use and how these skills help them to function in a technological society. The article presents author's research among a group of students of the University of the Third Age in Lublin.
\end{abstract}

Key words: University of the Third Age, LiveLong Learning, Education for elderly, media in education, computer workshops for elderly, knowledge of the media 


\section{Wprowadzenie}

Dzięki edukacji medialnej możliwe jest zdobywanie kompetencji, które są konieczne do swobodnego poruszania się w społeczeństwie. Mówiąc o edukacji medialnej, zapominamy o najstarszej grupie naszego społeczeństwa - pokoleniu, które dorastało w świecie analogowym, przez co cyfrowa rzeczywistość staje się dla niego wyzwaniem. Rozwój kompetencji medialnych seniorów wspiera ich wyjście z cienia wykluczenia cyfrowego. Współczesny świat poniekąd wymaga od osób starszych umiejętności adaptacji czynności, których wcześniej nie musieli podejmować. Do takiej aktywności należy korzystanie z komputera, Internetu i innych nowych mediów. Postępujące przemiany demograficzne wpływają na płaszczyzny takie jak: polityka, kultura, gospodarka, opieka medyczna ${ }^{1}$ i edukacja, zwłaszcza w kontekście rozwoju medialnym, którą chciałabym się zająć szerzej w tym artykule. Celem artykułu jest próba odpowiedzi na pytania, jak edukacja medialna wpływa na aktywność osób starszych, z jakich narzędzi internetowych korzystają najczęściej i dlaczego oraz jakie dobre praktyki funkcjonują w lubelskich instytucjach.

Edukacja przebiega we wszystkich etapach życia człowieka ${ }^{2}$. Zgodnie z ideą uczenia przez całe życie (ang. LLL - Lifelong Learning) ${ }^{3}$ proces nauczania powinien trwać również po zakończeniu nauki w szkole. Edukacja permanentna, zwana również ustawiczną, wspomaga osoby starsze w dążeniu do zapewnienia sobie potrzeb indywidualnych oraz w odnalezieniu się w danej społeczności $i^{4}$. Zwłaszcza w dobie wiedzy nabywanie oraz uzupełnianie kompetencji wydaje się konieczne, aby móc zrozumieć otaczającą rzeczywistość. Nabyte umiejętności pozwolą na swobodne poruszanie się w społeczeństwie informacyjnym ${ }^{5}$. W Polsce wzrasta populacja osób starszych, które mierzą się z różnego rodzaju ograniczeniami i stereotypami. Edukacja nie wyklucza rozwoju człowieka również w późnej dorosłości ${ }^{6}$. $\mathrm{Na}$ problemy te odpowiadają takie instytucje jak uniwersytety trzeciego wieku, które wspomagają utrzymanie więzi społecznych wśród seniorów: „Współczesne podejście do starości powoduje dostrzeganie potrzeby jak największej aktywizacji

${ }^{1}$ Ł. Tomczyk, Edukacja osób starszych, Seniorzy w przestrzeni nowych mediów, Warszawa 2015, s. 13.

2 T. Prauzner, Lifelong Learning - edukacja przez całe życie, Częstochowa 2011, s. 165.

${ }^{3}$ Hasło projektów dofinansowanych przez Unię Europejską, które mają na celu stworzenie jednolitej polityki odnośnie do edukacji niezależnie od wieku i posiadanego doświadczenia.

${ }_{4}$ M. Laal, Lifelong learning: What does it mean?, https://www.researchgate.net/publication/2247 67020_Lifelong_Learning_What_does_it_Mean [dostęp: 14.02.2018 r.], s. 473.

${ }^{5}$ D. Korzan, Kształcenie ustawiczne - przegląd literauty, http://www.korzan.edu.pl/pdf/ustawiczne.pdf [dostęp: 12.02.2018], s. 1 .

${ }^{6}$ Z. Hasińska, E. Tracz, Rola Uniwersytetów Trzeciego Wieku w aktywnym starzeniu się, Wrocław 2013, s. 91. 
ludzi starszych poprzez umożliwienie im kontaktów z rówieśnikami, zaspokojenie potrzeby samorozwoju, kształcenia się i zdobywania nowych umiejętności”" Uniwersytety trzeciego wieku integrują grupy osób starszych, umożliwiają formy spędzania wolnego czasu dostosowane do możliwości seniorów i w zgodzie z ich zainteresowaniami oraz proponują bogatą ofertę edukacyjną.

\section{Kształcenie seniorów w kontekście edukacji medialnej}

Edukacja medialna to interdyscyplinarna dziedzina kształcenia. Według G. Stunża to „proces kształtowania i upowszechniania umiejętności świadomego i krytycznego korzystania ze środków społecznego przekazu we wszystkich grupach społecznych oraz wiekowych. Proces edukacji medialnej to działania, które powinny trwać przez całe życie, ponieważ formy i technologie przekazu ulegają zmianom, a ponadto społeczeństwo także ulega ciągłym przeobrażeniom". Proces ten pozwala na zdobycie kompetencji medialnych, które są konieczne, aby świadomie wykorzystywać narzędzia technologiczne, w tym internetowe. Taka wiedza pozwala rozumieć mechanizmy medialne, potrafi wyselekcjonować informacje oraz w sposób bezpieczny i krytyczny umożliwić korzystanie z mediów.

Kształcenie seniorów z zakresu edukacji medialnej możemy realizować przez instytucje różnego typu:

- komercyjne (firmy szkoleniowe),

- oświatowe (uczelnie wyższe, placówki kształcenia ustawicznego),

- pozarządowe (stowarzyszenia),

- społeczne (kluby seniora),

- kulturalne (domy kultury).

- samodzielne uczenie w domu poprzez poradniki, tutoriale (np. na YouTube) ${ }^{9}$.

Ofertę edukacji medialnej znajdziemy w takich instytucjach, jak uniwersytety trzeciego wieku (w skrócie: UTW) czy w organizacjach pozarządowych, które zajmują się edukacją pozaformalną oraz upowszechnianiem tzw. nowych mediów. UTW są jedną z przodujących instytucji, jeśli chodzi o program dedykowany seniorom w całej Polsce, jak i w województwie lubelskim. Również Lubelski Uniwersytet Trzeciego Wieku reprezentuje dobre praktyki edukacyjne.

${ }^{7}$ J. Błaszczuk, I. Wróblewska, Uniwersytet Trzeciego Wieku jako instytucja aktywizująca osoby starsze - badania własne, Opole 2012, s. 31.

${ }^{8}$ G. Stunża, Edukacja medialna w podstawie programowej, https://nowoczesnapolska.org.pl/wp-content/uploads/2012/01/Cyfrowa-Przysz\%C5\%82o\%C5\%9B\%C4\%87-aneks-14.pdf, [dostęp: 2.01.2018], s. 2.

${ }^{9}$ Ł. Tomczyk, Seniorzy w świecie nowych mediów, „E-Mentor” 2010, nr 4 (36), s. 59. 


\section{Lubelski Uniwersytet Trzeciego Wieku szansą dla edukacji osób starszych w zakresie nowych technologii}

Jednym z głównych celów działań uniwersytetów trzeciego wieku jest umożliwienie osobom starszym przestrzeni do edukacji ustawicznej, w której znajdą merytorycznie treści dopasowane do osób z ich grupy wiekowej ${ }^{10}$. Działania tych uniwersytetów mają również ułatwić dostosowywanie się do przemian społecznych, kulturalnych czy globalnych oraz odpowiedniego reagowania na zmiany technologiczne. UTW cieszą się coraz większą popularnością z dwóch powodów. Po pierwsze wzrasta populacja osób starszych. Po drugie „trzeci wiek"11 to okres, który pozwala seniorom na aktywność w sferze pozarodzinnej i pozazawodowej ${ }^{12}$. W Polsce pierwszy UTW powstał w Warszawie w 1975 r., jedynie dwa lata po założeniu pierwszej takiej instytucji we Francji ${ }^{13}$. Dzięki inicjatywie Haliny Szwarc kolejne oddziały powstawały w większych miastach naszego kraju. Aktualnie istnieje ponad 614 takich ośrodków oraz filii1 ${ }^{14}$. Misją UTW jest wyrównanie szans między pokoleniami. Cel ten jest aktualny również dziś i nabiera głębszego znaczenia w przypadku edukacji związanej nowymi technologiami. Współczesna działalność UTW różni się innymi potrzebami edukacyjnymi niż w przeszłości. Obecny model starości skierowany jest na jak najdłuższe utrzymanie aktywności osób starszych.

W ofercie edukacyjnej Lubelskiego Uniwersytetu Trzeciego Wieku można było znaleźć kilka przedmiotów ze sfery medialnej. Były to zajęcia komputerowe, seminarium radiowe oraz seminarium wiedzy o mediach.

\section{Edukacja medialna na przykładzie Lubelskiego Uniwersytetu Trzeciego Wieku}

Celem badań podjętych przez autorkę wśród słuchaczy UTW w Lublinie było określenie profilu aktywności seniorów w aspekcie edukacji medialnej. Materiał empiryczny składał się z dwóch rodzajów danych. Pierwsza część badania miała charakter jakościowy, wykorzystano metodę zogniskowanych wywiadów grupowych.

10 Z. Szarota, Edukacja dorosłych w Polsce - wyzwania i możliwości, „Edukacja Dorosłych” 2003, nr 4, s. 19.

${ }^{11}$ Eufemistyczne określenie podeszłego wieku.

${ }^{12}$ E. Tracz, Z. Hasińska, Rola uniwersytetów trzeciego wieku w aktywnym starzeniu się, „Nauki Społeczne. Social Sciences" 2013, nr 1 (7), s. 92.

13 A. Marcinkiewicz, Uniwersytet Trzeciego Wieku jako instytucja przeciwdziałajaca marginalizacji osób starszych, „Ogrody Nauk i Sztuk” 2012, nr 2, s. 458.

14 Według badania GUS-u przeprowadzonego w $2016 \mathrm{r}$. 
Seniorzy odpowiadali na pytania otwarte dotyczące przyczyn, z jakich zapisali się na przedmioty związane z edukacją medialną oraz co podczas tych zajęć podobało im się najbardziej. Część rozmów została zarejestrowana na dyktafonie oraz spisana. Druga połowa badania miała charakter ilościowy. Przy pomocy ankiety seniorzy wskazali ulubione narzędzia sieciowe, z których korzystali słuchacze Uniwersytetu Trzeciego Wieku. W badaniach wzięło udział 20 osób w wieku 59-80 lat, w tym jedynie dwóch mężczyzn. Warto dodać, że były to osoby o różnym stopniu zaawansowania pod względem korzystania z nowych technologii. Przeprowadzone ankiety i wywiady dostarczyły cennych informacji związanych z relacjami senior - nowe media.

W roku akademickim 2014/2015 w ofercie LUTW znalazło się seminarium wiedza o mediach skierowane do słuchaczy roku wstępnego. Seniorzy mogli wybrać pomiędzy tymi zajęciami a wiedzą o kulturze lub seminarium radiowym. Zajęcia odbywały się w ramach tzw. roku wstępnego dla początkowych słuchaczy. Warsztaty komputerowe były fakultatywne i odpłatne.

$\mathrm{Na}$ pytanie, $\mathrm{z}$ jakich przyczyn seniorzy zapisują się na zajęcia wiedzy o mediach, słuchacze odpowiedzieli następująco:

- Uważałam, że mój zakres wiedzy jest niewystarczajacy jak na dzisiejsze czasy. (Elżbieta, 61 l., wykształcenie wyższe).

- Chciałam bliżej poznać media, ich rozwój i zastosowanie w życiu codziennym. (Teresa, 68 1., wykształcenie wyższe).

- Podnoszenie umiejętności i rozwijanie zdrowia psychicznego.

(Elżbieta, 60 l., wykształcenie policealne).

- Poszerzenie wiedzy.

(Edyta, 67 l., wykształcenie policealne).

- Celem uaktualnienia wiedzy.

(Ewa, 67 l., wykształcenie policealne).

Seniorzy, którzy zgodzili się na uczestnictwo w badaniu, byli świadomi tego, jak edukacja medialna może wpłynąć na ich życie, i zapisywali się na zajęcia z konkretnych powodów.

Osoby starsze chętnie odpowiadały na pytania, były świadome konieczności poznawania medium, jakim jest komputer - rozumieją, że nawet podstawowa znajomość posługiwania się technologiami pozwoli im ułatwić życie codzienne oraz dostęp do informacji. Seniorzy wskazywali, że ich motywacją podczas edukacji medialnej był odpowiedni prowadzący. Wskazywali, że powinny być to osoby charyzmatyczne, cierpliwe i otwarte. Osoby starsze łatwo się zniechęcają oraz obawiają ośmieszenia z powodu niewiedzy.

W celu zdiagnozowania, które aplikacje, programy i usługi są najciekawsze oraz najpotrzebniejsze w użytkowaniu nowych mediów, seniorzy wybrali następujące 
narzędzia (z możliwością zaznaczenia kilku opcji). Narzędzia te zaproponował Ł.Tomczyk w swoim artykule Seniorzy $w$ świecie nowych mediów ${ }^{15}$. W związku z tym, że grupa była nieliczna, przedstawiono liczbę seniorów w procentach. W badaniu wzięło udział dwadzieścia osób.

Tab. 7. Najchętniej wykorzystywane narzędzia internetowe przez słuchaczy LUTW

\begin{tabular}{|l|c|}
\hline \multicolumn{1}{|c|}{ Przykładowe narzędzie: } & $\begin{array}{c}\text { Liczba seniorów } \\
\text { w procentach }\end{array}$ \\
\hline Narzędzia biurowe & $40 \%$ \\
\hline Narzędzia liczące & $30 \%$ \\
\hline Przeglądanie internetu & $90 \%$ \\
\hline Komunikatory, np. Skype & $90 \%$ \\
\hline Obrabianie zdjęć/ tworzenie grafiki & $35 \%$ \\
\hline Obróbka filmów & $5 \%$ \\
\hline Nauka języków & $49 \%$ \\
\hline Nauka przez internet & $15 \%$ \\
\hline Rozrywka & $50 \%$ \\
\hline Oglądanie filmów & $45 \%$ \\
\hline Archiwizacja danych na nośnikach zewnętrznych & $50 \%$ \\
\hline Dokonywanie zakupów online & $30 \%$ \\
\hline Poznanie zagrożeń sieciowych & $20 \%$ \\
\hline Korespondencja e-mailowa & $90 \%$ \\
\hline Rezerwacje biletów przez internet & $95 \%$ \\
\hline Wysyłanie PIT-u do urzędu skarbowego & $30 \%$ \\
\hline Instalowanie aplikacji & $25 \%$ \\
\hline Instalowanie sprzętu & $25 \%$ \\
\hline Bankowość elektroniczna & $40 \%$ \\
\hline Triale, e-learning & $10 \%$ \\
\hline Rozwijanie pasji & $30 \%$ \\
\hline Inne: & \\
\hline Prasa & $5 \%$ \\
\hline Zno: Bara & \\
\hline
\end{tabular}

Źródło: Badania własne.

15 Ł. Tomczyk, Seniorzy w świecie nowych mediów, http://www.e-mentor.edu.pl/artykul/index/ numer/36/id/776 [dostęp: 2.12.2017], s. 56. 
Różne etapy życia człowieka wymagają zaspokajania odrębnych potrzeb ${ }^{16}$. Umiejętne wykorzystanie przez seniorów mediów pozwoli na asymilację technologiczną. Nowe media to dobre narzędzie dla rozrywki, komunikacji oraz pracy. Popularnością wśród seniorów cieszył się program do komunikacji audiowizualnej Skype, który pozwala na utrzymywanie kontaktu z rodziną przebywającą zagranicą ( $90 \%$ osób badanej grupy wskazało właśnie ten program). W tym samym stopniu słuchacze zainteresowali się przeglądaniem Internetu oraz możliwością dobierania treści według własnego gustu. Najmniej ciekawe dla seniorów okazały się narzędzia najtrudniejsze w obsłudze (obróbka filmów) oraz czytanie prasy na ekranie monitora (prawdopodobnie preferują tradycyjną formę). W związku z tym, że nasze społeczeństwo ma charakter starzejący się, seniorzy są atrakcyjną grupą odbiorców dla dóbr medialnych.

Oprócz zajęć pod nazwą bliżej współczesności seniorzy mogli wybrać dla siebie seminaria tematyczne i zajęcia dodatkowe, m.in.: seminarium radiowe, seminarium wiedzy o kulturze, seminarium wiedzy o mediach, seminarium historii sztuki, komputery, gimnastyka, ruch przy muzyce. W cenie opłat wstępnych seniorzy mogli korzystać z wykładów ogólnouniwersyteckich (z wiedzy ogólnej, przyrodniczej i medycznej), zajęć integracyjnych oraz zajęć dodatkowych i kół zainteresowań.

Seniorzy zapytani o to, co było dla nich najciekawsze na zajęciach z wiedzy o mediach, odpowiedzieli:

- To dobre połaczenie wiedzy i praktyki.

(Elżbieta, 68 1.).

- Najciekawsze dla mnie było użytkowanie mediów w innych państwach, Internet $w \dot{z} y$ ciu każdego człowieka $i$ stosowanie go na co dzień.

(Teresa, 68 1.).

- Najbardziej podobat mi się sposób prowadzenia przez wykładowcę. (Danuta, 61 1.).

- Cieszę się z tych informacji, które wcześniej nie były nigdzie publikowane. (Anna, 62 1.).

- Nauczyłam się, jak właściwie odbierać informacje przekazywane przez media. (Halina, 66 1.).

W dalszej części ankiety na pytanie, co było dla nich najciekawsze na zajęciach $\mathrm{z}$ wiedzy o mediach, odpowiadali:

- Połaczenie wiedzy z praktyka.

- Media w innych państwach. Internet w życiu każdego człowieka. Stosowanie go na co dzień.

- Sposób prowadzenia przez wykładowcę.

16 Tamże, s. 57. 
- Informacje nigdzie niepublikowane.

- Jak właściwie odbierać informacje przekazywane przez media.

- Jak funkcjonuja media.

Jedynie czterech seniorów odpowiedziało twierdząco na pytanie, czy znają określenie „nowe media”. Jedna z osób podała swoją własną definicję: „nowe media to coś więcej niż komputery, to też Internet i wszystkie nowinki technologiczne z nim związane”.

Badani wymienili również, jaką wiedzę wynieśli z zajęć wiedza o mediach:

- Poszerzyłam swoja wiedze.

- Poszerzyłam wiedze o mediach. Poznałam media zagraniczne, zastosowanie Internetu $w \dot{z} y c i u$ codziennym.

- Uświadomienie zagrożenia.

- Pogłębienie wiedzy, przypominanie.

- Pogłębianie wiedzy.

- Wprawę.

Część seniorów (6 osób) uważa, że przez własną pomniejszoną adaptację nowych mediów zwiększa się różnica pokoleniowa. Jedna $\mathrm{z}$ ankietowanych nie rozumie tak wielkich potrzeb ani zainteresowania młodego pokolenia komputerami i Internetem. Dwie osoby zaznaczyły, że nieużytkowanie mediów nie wpływa na ich relacje $z$ otoczeniem. Seniorzy chętnie opowiadali o swoich doświadczeniach z zakresu użytkowania mediów, chętnie dyskutowali o swoich doświadczeniach oraz podsumowywali, czego się nauczyli.

\section{Zajęcia komputerowe dla seniorów}

Każdego roku akademickiego dużym zainteresowaniem cieszą się zajęcia komputerowe. Seniorzy często podkreślają, że zapisują się na UTW, aby skorzystać z wiedzy przekazywanej na tym przedmiocie. Co roku powstają dwie grupy zaawansowania:

- podstawowa (dla osób, które w ogólnie nie mają doświadczenia w pracy $\mathrm{z}$ komputerem),

- średnio zaawansowana.

Zajęcia prowadzone są w małej liczbie osób w pracowni komputerowej.

Część seniorów, którzy zapisują się na zajęcia, wcześniej nie użytkowała komputera, głównie z powodu nieposiadania takiego sprzętu, braku potrzeby lub niewiedzy o możliwościach sprzętu technicznego. Zapytani, dlaczego zapisali się na zajęcia komputerowe, przedstawili następujące odpowiedzi:

- Poznanie podstaw postugiwania się komputerem (e-mail, Skype, robienie zakupów, archiwizowanie). 
- W celu poznania dodatkowych informacji i programów oraz utrwalenia znanych mi informacji. Poznanie ludzi i ewentualny kontakt przez Internet.

- By móc mieć kontakt ze światem i z bliskimi oraz czytać prasę, poszukiwać informacji.

- W celu nauczenia się obsługi komputera.

Jedna ze słuchaczek napisała, że nie potrzebuje zajęć komputerowych, bo $\mathrm{w}$ przeszłości pracowała jako informatyk.

Seniorzy podali też powody, dla których warto uczęszczać na zajęcia komputerowe:

- Warto chodzić, by bez obaw korzystać z komputera, wykorzystywać jego walory do codziennego użytku (zakupy, wiadomości, banki itp.).

- Powiększenie wiedzy, poznanie nowych programów. Nabranie swobody poruszania się w Internecie, oswajanie się z Internetem, nabranie pewności i samodzielności w obstudze komputera.

- W obecnej chwili wiedza komputerowa jest niezbędna.

- Dla mnie wszystko było nowością, więc warto.

- Warto, ale jeśli będa mniej płatne jak w innych miastach.

- Zapisuja się Ci, którzy sobie nie radzą.

- Nie uciekniemy od komputerów.

$\mathrm{Na}$ podstawie powyższych wypowiedzi możemy stwierdzić, że seniorzy są świadomi konieczności poznawania medium, jakim jest komputer - rozumieją, że nawet podstawowa znajomość pozwoli im ułatwić życie. Zajęcia oraz warsztaty zwiększają świadomość seniorów, że podnoszenie kwalifikacji pomoże im w eliminowaniu leków i barier, które odczuwają wobec nowych technologii ${ }^{17}$. Włączenie osób starszych do całej,,technologicznej machiny” może przynieść również profity w postaci komunikacji międzypokoleniowej. Podtrzymywanie kontaktu w języku nowych mediów z młodszym pokoleniem może przywrócić seniorom godność, przełamać negatywne stereotypy, jak i przywrócić osobie starszej ważną rolę w społeczeństwie czy w rodzinie ${ }^{18}$.

${ }^{17}$ M. Urbańska-Bulas, Czego Jaś się nie nauczył... to Jan może się nauczyć... czyli o kształceniu ustawicznym słów kilka... http://www.kwalifikacjetopodstawa.cedego.pl/dzial.php?id=2\&id2=4 [dostęp: 11.06.2014r.]

${ }_{18}$ R. Błaszkiewicz, Globalna sieć dla surfujących seniorów, [w:] Historyczno-społeczne aspekty starzenia się i starości, red. M. Stawiak-Ososińska, Kielce 2014, s. 19. 


\section{Podsumowanie}

Uzyskane wyniki pozwalają wnioskować, że edukacja medialna seniorów jest potrzebna i zasadna. Istnieje konieczność organizowania kursów oraz szkoleń, które pozwolą osobom starszym na rozwijanie kompetencji medialnych. Spoczywa na nas odpowiedzialność społeczna, aby motywować seniorów do korzystania z nowych technologii. Uczestnicy badanej grupy rozumieją, jakie możliwości otwiera korzystanie z komputera i Internetu. Zauważają, jak ich wnuki z pasją korzystają z tych środków medialnych. Wypowiedzi dotyczyły postaw wobec korzystania $\mathrm{z}$ technologii, powodów podjęcia nauki oraz podnoszenia kwalifikacji, przebiegu procesu nauczania, roli technologii w życiu oraz korzyści i obaw wynikających z użytkowania komputera i Internetu.

Współcześni seniorzy nie mieli możliwości zapoznać się z technologiami w takim stopniu, jak młodsze pokolenie. Rozbieżność pokoleniowa w ujęciu technologicznym zależy również od sytuacji finansowej, wykształcenia, stanu zdrowia czy miejsca zamieszkania. Sytuację tę pogłębia niewystarczająca lub zbyt skomplikowania oferta edukacyjna, która nie zaspokaja istniejących potrzeb osób starszych, pogłębia przepaść technologiczną. Edukacja przez całe życie jest częścią aktywności obywatelskiej, a zadaniem naszego pokolenia jest umiejętne odnalezienie efektownych sposobów ustawicznego uczenia się ${ }^{19}$. Podjęcie odpowiednich działań wesprze najstarszą grupę naszego społeczeństwa w aktywnym, umiejętnym i systematycznym użytkowaniu nowych technologii. W uzyskaniu takiego efektu pomoże właśnie edukacja medialna dostosowana do możliwości osób starszych. Uniwersytety trzeciego wieku są jedną z głównych instytucji skierowanych do osób w podeszłym wieku ${ }^{20}$. Z każdym kolejnym rokiem pozyskują słuchaczy, którzy dobrowolnie wdrażają się w system kształcenia.

\section{BIBLIOGRAFIA}

Aleksander T., Andragogika. Podręcznik akademicki, Radom-Kraków 2009. Błaszczak J., Wróblewska I., Uniwersytet Trzeciego Wieku jako instytucja aktywizujaca osoby starsze - badania własne, Opole 2012.

${ }^{19}$ L. Burns, Uczenie się przez całe życie $w$ starzejącym się spoleczeństwie, [w:] Seniorzy w społeczeństwach Europy XXI wieku - wspóttworzenie i współodpowiedzialność, red. W. Pędich, Białystok 2001, s. 93.

20 T. Aleksander, Andragogika. Podręcznik akademicki, Radom-Kraków 2009, s. 292. 
Błaszkiewicz R., Globalna sieć dla surfujących seniorów, [w:] Historyczno-społeczne aspekty starzenia się i starości, red. M. Stawiak-Ososińska, A. Szplit, Kielce 2014.

Burns L., Uczenie się przez całe życie w starzejacym się spoleczeństwie, [w:] Seniorzy w społeczeństwach Europy XXI wieku - współtworzenie i współodpowiedzialność, red. W. Pędich, Białystok 2001.

Marcinkiewicz A., Uniwersytet Trzeciego Wieku jako instytucja przeciwdziałajaca marginalizacji osób starszych, „Ogrody Nauk i Sztuk” 2012, nr 2.

Pędich P., Seniorzy w społeczeństwach Europy XXI wieku - współtworzenie i wspótodpowiedzialność, Białystok 2001.

Prauzner T., Lifelong Learning - edukacja przez całe życie, Częstochowa 2011.

Sikorski W., Edukacja w zakresie technologii informacyjnej na uniwersytetach trzeciego wieku, [w:] Seniorzy w świecie technologii. Implikacje dla praktyki edukacyjnej oraz rozwoju społeczeństwa informacyjnego, red. Ł. Tomczyk, A. Wąsiński, Katowice 2012.

Szarota Z., Edukacja dorosłych w Polsce - wyzwania i możliwości, „Edukacja Dorosłych" 2003, nr 4.

Tomczyk Ł., Edukacja osób starszych, Seniorzy w przestrzeni nowych mediów, Warszawa 2015.

Tracz Ł., Hasińska Z., Rola Uniwersytetów Trzeciego Wieku w aktywnym starzeniu się, „Nauki społeczne. Social Sciences” 2013, nr 1 (7).

Tracz E., Hasińska Z., Rola Uniwersytetów Trzeciego Wieku w aktywnym starzeniu się, Wrocław 2013.

\section{Źródła internetowe:}

Korzan D., Kształcenie ustawiczne - przeglad literatury, http://www.korzan.edu.pl/ pdf/ustawiczne.pdf [dostęp: 12.02.2018].

Laal M., Lifelong learning: What does it mean?, https://www.researchgate.net/publication/224767020_Lifelong_Learning_What_does_it_Mean [dostęp: 14.02.2018].

Stunża G., Edukacja medialna w podstawie programowej, https://nowoczesnapolska.org.pl/wp-content/uploads/2012/01/Cyfrowa-Przysz\%C5\%82o\% C5\%9B\%C4\%87-aneks-14.pdf, [dostęp: 2.01.2018].

Tomczyk Ł., Seniorzy w świecie nowych mediów, http://www.e-mentor.edu.pl/arty$\mathrm{kul} / \mathrm{index} /$ numer/36/id/776 [dostęp: 1.02.2018].

Urbańska-Bulas M., Czego Jaś się nie nauczył... to Jan może się nauczyć... czyli o kształceniu ustawicznym słów kilka... [dostęp: 3.12.2017]. 